\title{
IAMJ
}

INTERNATIONAL

AYURVEDIC

MEDICAL JOURNAL

\section{A CRITICAL REVIEW STUDY ON MADHUMEHA (DIABETES MELLITUS) AND ITS PREVENTIVE APPROACH}

\author{
Alisha Dhaaniya ${ }^{1}$, Prateek Madan ${ }^{2}$, Ravi Sharma ${ }^{3}$, N. R. Singh ${ }^{4}$ \\ ${ }^{1,2,3}$ PG Scholar, Department of Kayachikitsa, Ch. Brahm Prakash Ayurveda Charak Sansthan, Khera Dabar, \\ Najafgarh, New Delhi 110073, India \\ ${ }^{4}$ Professor \& H.O.D, Department of Kayachikitsa, Ch. Brahm Prakash Ayurveda Charak Sansthan, Khera Dabar, \\ Najafgarh, New Delhi 110073, India
}

Corresponding Author: alishadhaniya@gmail.com

\section{https://doi.org/10.46607/iamj4109102021}

(Published Online: October 2021)

Open Access

(C) International Ayurvedic Medical Journal, India 2021

Article Received: 01/10//2021 - Peer Reviewed: 08/10/2021 - Accepted for Publication: 11/10/2021

\section{Check for updates}

\begin{abstract}
Madhumeha is a clinical entity described in Ayurveda under the types of Vataja Prameha. It is caused by the aggravation of Vata, the patient passes excess urine, which is sweet, astringent in taste, slightly turbid and pale in colour. Madhumeha can be correlated with an identical disease delineated in modern medical sciences as Diabetes Mellitus. DM has turned out to be the considerable silent killer today within the world. In Ayurveda it is described in Vataja Pramehas and can be managed conservatively with Modifications in diet, exercise, medication and lifestyle are all important factors in the successful treatment of type 2 diabetes and are assimilated into the ancient Indian medicinal practice of Ayurveda. Drugs like Chandraprabha (Curcuma zedoaria), Gudmar (Gymnema sylvestre), Asana (Pterocarpus marsupium), Musta (Cyperus rotundus), Shilajit (Purified Bitumen), Khadir (Acacia catechu), Vacha (Acorus calamu), Guduchi (Tinospora cordifolia), Jambu (Syzygium cumini) are effective in controlling hyperglycemia. This study is consists of a brief classical picture of Madhumeha and Type 2 Diabetes Mellitus along with its burden on society and classical management.
\end{abstract}

Keywords: Chandraprabha, Diabetes Mellitus, Madhumeha, Prameha, Vataja. 


\section{INTRODUCTION}

Prameha has been mentioned that it is a group of disorders in which there is an increased frequency of micturition, the volume of urine is also increased, and the urine becomes turbid. Acharyas have explained that in Madhumeha there is vitiation of Vata Kapha Pradhana Tridosha associated with Meda and other Dhatus along with Ojas as Dushya which comes out of the body through Mutravaha Srotas. A similar disease has been described in modern medical sciences as Diabetes Mellitus.

Type2 Diabetes Mellitus (DM) refers to a group of metabolic disorders characterized by chronic hyperglycaemia, polyuria, polydipsia, polyphagia, emaciation, and weakness due to disturbance in carbohydrate, fat and protein metabolism associated with a relative or absolute deficiency in insulin secretion and/or insulin action ${ }^{1}$.

Globally approximately 422 million adults are suffering from Diabetes Mellitus, according to the latest 2016 data of the World Health Organization. The prevalence of Diabetes Mellitus is increasing quickly; the previous year of 2013, according to the International Diabetes Federation put the number at 381 million people having Diabetes. (The number is projected to be almost double by $2030 .^{2}$

Among the several health disorders, diabetes and its complications account for a massive hazard to future public health resources all over the globe. Ayurvedic formulations are used to treat a wide variety of diseases including Type 2 Diabetes Mellitus described as Madhumeha in Ayurvedic texts. In Allopathic practice, most of the hypoglycemic agents used to treat Type2 Diabetes Mellitus and hyperlipidaemia are reported to have side effects on long term use. Hence, there is the necessity to look for effective and safe drugs for these health problems.

\section{AIM AND OBJECTIVES:}

To review the analytical concept of Prameha/Madhumeha Roga, from different Ayurvedic literature.

\section{MATERIAL AND METHOD:}

Material Review of literature is presented hereafter thorough study of Ayurvedic classics, journals, inter- net and the latest research papers published in its context and compiling references from Ayurvedic as well as Modern Medical texts and previous research work on this subject.

\section{REVIEW OF LITERATURE:}

The etymology of Prameha:

The word Prameha consists of two words i.e., Pra (Upsarga-Prefix) and Meha. ${ }^{3}$

प्रमेह $=$ प्र + मिह

The word springs from the root "Mih Sechane" by adding 'lue' Pratyaya to it.

मेहति सिज्चति मूत्ररेतांसि ।

\section{The etymology of Madhumeha:}

The word Madhumeha comprises two words i.e., Madhu and Meha. The word Madhu is acquired from the root "Manyante Visheshena Janati Jana Yasmin". The root -" Manjane"' is applied by Dha Adesha and it shows the similarity of urine in taste, colour and appearance etc. The word Meha was first found in Rigveda as Mehanadthanam Karanallium ${ }^{4}$.

Madhumeha can be defined as follows.

सर्व एव प्रमेहा मूत्रादिमाधुर्ये मधुगंध सामान्यात् पारिभाषिकी मधुमेहाख्या लभन्ते । (Su. Chi. 12/6)

It is a clinical condition in which the patient voids the urine which has similarity with Madhu i.e., Kashaya (astringent) and Madhura (sweet) Rasa (taste), Rukshatwa (dry) and Madhu (honey) like colour and body acquires sweetness is called Madhumeha.

मधुमेही मधुसमम्। A.H.Ni.10/18)

कषायं मधुरं रूक्षं क्षौद्रमेहं वदेद्द बुधः (A.S.Ni.10/3)

क्षौद्र रसवर्ण क्षौद्रमेही। (Su.Ni.6/14)

\section{Aetiology ${ }^{5}$}

आस्यासुखं स्वप्रसुखं दधीनि ग्राम्यौदकानूपरसाः पयांसि| नवान्रपानं गुडवैकृतं च प्रमेहहेतु: कफकृच्च सर्वम्| (Ch. Chi. 6/4)

Asyasukham - Comfortable seating (luxury, sedentary lifestyle, lack of physical activities and exercise), Svapnasukham - comforts of sleeping, excess sleeping, Dadhini-eating curd in excess, Gramyaudakanupa rasaah- meat of domestic, aquatic and marshy land animals, Excessive intake of milk products, Navannapaanam-foods made of freshly har- 
vested grains \& freshly prepared alcoholic drinks, Gudavaikritam- jaggery preparations or sweets, Kaphakrut Cha Sarvam - All diet and sedentary lifestyle activities which increase Kapha Sahaja (inherited factor $)^{6}$

\section{Samprapti (Pathogenesis):}

Madhumeha can originate in two ways

1. Avaranjanya (By the obstruction of Vata caused by Doshas covering it)

2. Dhatukshayajanya (Depletion in body tissues causes aggravation of Vata)

In Avaranjanya Madhumeha the vitiated Kapha Dosha and Meda Dhatu (Fat tissue) obstruct the passage of Vata Dosha. In the process of manifestation of Madhumeha, the obstructed Vata is vitiated again and carries Oja to Basti (Urinary Bladder). Dhatukshayajanya Madhumeha (Diabetes caused by depletion in body tissues causes aggravation of Vata) manifests as a thin and asthenic individual due to loss of Oja. All this is Ojakshaya meaning an imbalance in $\mathrm{Oja}^{7}$

Vitiating factors involved in pathogenesis:

कफः सपित्तः पवनश्च दोषा मेदोऽ स्रशुक्राम्बुवसालसीकाः|

मज्जा रसौजः पिशितं च दूष्याः [?] प्रमेहिणां, विंशतिरेव मेहा:॥ (Ch. Chi 6/8)
Doshas (Kapha, Pitta and Vata) and Dushyas like Medas (fat tissue), Rakta (blood tissue), Shukra (semen), Ambu (body fluid), Vasa (muscle fat), Lasika (lymph), Majja (bone marrow tissue), Rasa, Ojas (immunity) and Mamsa (muscle tissue) are responsible for the causation of Prameha which is of twenty types. ${ }^{8}$

According to the Ayurveda, in the potency of the feature of aetiology, Dosha (innate pathogenic factors) and Dushyas (substratum of pathology), the response occurs in the form of non-manifestation or otherwise of the disorders. When these three factors do not combine or if combined after a long time or in a weakened state, the disorder will not be there, or it will manifest lately or can be manifest in a mild form or without of the symptoms. ${ }^{9}$

\section{Risk factors}

1. Family history

2. Obesity $(\mathrm{BMI}>27 \mathrm{~kg} / \mathrm{m} 2)$

3. Age $>45$ years

4. Hypertension (B.P. > 140/ $90 \mathrm{~mm}$ of $\mathrm{Hg}$ )

5. $\mathrm{HDL}<35 \mathrm{mg} / \mathrm{dl}$ and/ or triglycerides levels > $250 \mathrm{mg} / \mathrm{dl}$

6. Habitual physical inactivity

\section{Classification}

Table 1: Classification of Prameha-

\begin{tabular}{|c|c|c|}
\hline S. No. & Classification & Types \\
\hline 1 & Etiological (Sh.Ci.11/3) ${ }^{10}$ & $\begin{array}{l}\text { a) Sahaja or Kulaja (Hereditary) } \\
\text { b) Apathyanimittaja (Acquired) }\end{array}$ \\
\hline 2 & Clinicopathological (Doshik)(A.H.Ni.10/1) ${ }^{11}$ & $\begin{array}{l}\text { a) Kaphaj - } 10 \text { types } \\
\text { b) Pittaj - } 6 \text { subtypes } \\
\text { c) Vataj - } 4 \text { subtypes }\end{array}$ \\
\hline 3 & Constitutional & $\begin{array}{l}\text { a) Sthula or Balvana (Obese Type2DM) } \\
\text { b) Krisha or Daurbalya (Asthenic Type1DM) }\end{array}$ \\
\hline $\begin{array}{l}4 \\
.\end{array}$ & Prognostic & $\begin{array}{l}\text { a) Sadhya (Curable) } \\
\text { b) Yaapya (Pallable) } \\
\text { c) Aasadhya (Incurable) }\end{array}$ \\
\hline
\end{tabular}

\section{Premonitory signs and symptoms}

स्वेदोऽड़गगन्धः शिथिलाड्गता च शय्यासनस्वप्नसुखे रतिश्च| हृत्रेत्रजिह्वाश्रवणोपदेहो घनाड़॰ता केशनखातिवृद्धिः॥
शीतप्रियत्वं गलतालुशोषो माधुर्यमास्ये करपाददाहः भविष्यतो मेहगदस्य रूपं मूत्रेऽभिधावन्ति पिपीलिकाश्च|| (Ch. Chi 6/13-14) 
Excessive Sweating, foul odour from body, flabbiness of the body, liking for constantly lying on the bed, sitting, sleeping and leading an easy life, a feeling as if the cardiac region is covered with immaterial, execration from eyes, tongue and ears, plumpness of the body, excessively growing hair and nails, liking for cold things, dryness of throat and palate, sweet taste in the mouth, burning sensation in hands and legs and attraction of ants towards the urinethese are the Purvaroop (premonitory signs and symptoms) of Prameha. ${ }^{12,13}$

\section{Clinical Features}

Avila prabhuta mutra ${ }^{14}$ - Excessive passage of turbid urine.

1. Increased frequency of urine (Polyuria)

2. Increased appetite (Polyphagia)

3. Excessive thirst (Polydypsia)

4. Turbidity in urine

5. Debility/ tiredness

6. Weight loss

7. non-healing ulcer

8. Visual disturbances

9. Inflammation of glans penis

In elderly patients with diabetes, the presentation of symptoms may be significantly different from the classic triad of polyphagia, polyuria, and polydipsia and weight loss. They may present with anorexia, failure to thrive, loss of motivation, fatigue, anorexia, failure to thrive, loss of motivation and difficulty in concentration.

\section{Complications}

The following complications may occur in the later stage of Diabetes mellitus:

1. Burning sensation over palmar and plantar region (Diabetic neuropathy)

2. Boils and carbuncles

3. Gangrene

4. General debility

5. Retinopathy

6. Renal tissue damage (nephropathy)

7. cardiovascular diseases

Investigations

Disease-Specific

i. Measurement of the plasma glucose level a. Random blood sugar (RBS)

b. Fasting blood sugar (FBS)

c. Postprandial blood sugar (PPBS)

ii. Urine routine and microscopic

iii. Glycosylated haemoglobin (HbA1c)

iv. Lipid Profile

\section{Other related Investigations}

i. Blood urea and serum creatinine

ii. E.C.G.

iii. Fundus examination

iv. Serum electrolytes

\section{Diagnostic Criteria for the Diagnosis of Diabetes} Mellitus $^{15}$ :-

1. Fasting: -

- Normal- < $110 \mathrm{mg} / \mathrm{dl}$

- Impaired fasting glucose level $>110$ and $<126$ $\mathrm{mg} / \mathrm{dl}$

- Diabetes mellitus- $\geq 126 \mathrm{mg} / \mathrm{dl}$

2. Random plasma glucose level $>200 \mathrm{mg} / \mathrm{dl}$ (or)

3. Two hours prandial glucose level $>200 \mathrm{mg} / \mathrm{dl}$

- Normal- < 140 mg/dl

- Impaired glucose tolerance level- > 140 and < 200 $\mathrm{mg} / \mathrm{dl}$

- Diabetes mellitus- > $200 \mathrm{mg} / \mathrm{dl}$ with symptom

The diagnosis is made by collaborating symptoms and plasma glucose levels

Management approaches

Prevention of Prameha

यैर्हेतुभिर्ये प्रभवन्ति मेहास्तेषु प्रमेहेषु न ते निषेव्याः|

हेतोरसेवा विहिता यथैव जातस्य रोगस्य भवेच्चिकित्सा|| (Ch-Chi: 6/53)

The causative factors responsible for the manifestation of different types of Prameha should be avoided. The already described causative factors can be avoided during the treatment of those diseases (even after their manifestation).

\section{A. Some Preventive Methods}

1. Usage of Yava (barley), Mudga (green gram), pumpkin, cucumber, old rice, bitter gourd, drumstick, Methi (fenugreek), Patola (snake gourd), Bimbi, watermelon, buttermilk, Triphala etc. is beneficial as preventive measures for diabetic Mellitus patients.

2. Dinacharya (daily regimen) and Ritucarya (seasonal regimen) 
3. Control in Carbohydrates intake.

4. Daily Exercise (Brisk walking, swimming etc- 30 minutes for 4-5 days/week.)

5. Regular consumption of Rasayana drugs (Amalaki rasayana etc.)

6. Restriction in intake of sugar/ sugar products, dairy products and fried food.

7. Restriction in the intake of different types of wine, cakes, excess use of oil, clarified butter, milk, sugarcane products and the meat of domestic and aquatic animals

8. Avoidance sleep during daytime.

b. medical management

Line of treatment:

1. Nidana parivarjana (Avoidance of causative factors) - Avoidance of fat, carbohydrate, sugar, tubers, sweets, dairy products, soft drinks, fried foods and sweet fruits like mango, banana, custard apple and date.

\section{Specific Therapies}

Chikitsa Sutra:

स्थूलः प्रमेही बलवानिहैक: कृशस्तथैक: परिदुर्बलश्च । संबृहणं तत्र कृशस्य कार्य संशोधनं दोषवलाधिकस्य ॥ (Ch. Chi. $6 / 15)^{16}$.

If a diabetic patient is having obesity, then Samshodhana chikitsa (bio-purification therapies) like- Vamana (emesis), Virechana (purgation) and Basti (enema) are to be performed after proper assessment of the patient. If a diabetic patient is lean and thin, then only Shamana chikitsa (Palliative therapy) should be recommended.

संशोधनोल्लेखनलड्धनानि काले प्रयुक्तानि कफप्रमेहान्| जयन्ति पित्तप्रभवान् विरेक: सन्तर्पणः संशमनो विधिश्च॥

Purificatory/cleansing therapies including specifically Ullekhan or Vaman (emesis) and Langhan (fasting therapies) are administered at the appropriate time, to cure Kaphaja types of Prameha. Similarly, Virechan (purgation), Santarpana (nourishing therapy) and alleviation therapies should be administered to treat Pittaja types of Prameha. ${ }^{17}$

Drug therapies - In Ayurveda, mostly drugs indicated in diabetes mellitus regulate the glycaemic index by their action on beta-cell of pancreas thus improving insulin production/increasing insulin sensitivity. The following drugs/ formulations are useful to control type II diabetes mellitus which can be correlated with Madhumeha as described earlier. In type I diabetes mellitus, these drugs can be used as supportive therapy in addition to conventional insulin therapy to prevent long term complications.

\section{Pacification Treatment}

\begin{tabular}{|c|c|c|c|}
\hline Type & Medicine & Dose & Time \\
\hline \multirow[t]{6}{*}{ Kapha dominant } & 1. Juice of Bilva leaves & $10-20 \mathrm{ml}$ & Between two meals, two times \\
\hline & 2. Juice of nimba leaves & $10-20 \mathrm{ml}$ & Between two meals, two times \\
\hline & 3. Shilajatu rasayana & $250-500 \mathrm{mg}$ & Between two meals, two times \\
\hline & 4. Chandraprabha & $250-500 \mathrm{mg}$ & Between two meals, two times \\
\hline & 5. Lodhrasava & $10-20 \mathrm{ml}$ & Between two meals, two times \\
\hline & 6. Asanadi kwatha & $10-20 \mathrm{ml}$ & Between two meals, two times \\
\hline \multirow[t]{3}{*}{ Pitta dominant } & 1. Shatavryadi decoction & $20-40 \mathrm{ml}$ & Between two meals, two times \\
\hline & 2. Jambavasava & $10-20 \mathrm{ml}$ & Between two meals, two times \\
\hline & 3. Vasanta kusumakar rasa & $60-120 \mathrm{mg}$ & Between two meals, two times \\
\hline \multirow[t]{2}{*}{ Vata dominant } & 1. Trivanga bhasma & $120-500 \mathrm{mg}$ & Between two meals, two times \\
\hline & 2. Vasanta kusumakar rasa & $60-120 \mathrm{mg}$ & Between two meals, two times \\
\hline
\end{tabular}

Various Shamanyoga which can be used in treatment of Madhumeha:

1. Dravya yoga-Salsaradi Nyagrodhadi

2. Swarasa-Bilavapatra. Guduchi, Satavari, Haridra, Amalaki
3. Choorna-Mammajak, Nimba, Jambu Beeja, Eladi Nyagrodhadya. Amalaki, Haridra

4. Kwatha- Phalatrikadi, Asanadi, Mustadi, Triphaladi. Vidangadi (Y.R.)

5. Gutika-Chandraprabha, Gokshuradi guggulu. 
6. Avaleha- Bangavaleha, Salaradhi. Kushavaleha.

7. Paka- Puga paka, Aswagandha pak (Y.R.)

8. Ghrita- Dhana Vata r. Trikantakadhya, Mahadadi madya.

9. Asava-arishta- Lodhrasava. Dantyasava, Jambvasa Loharista, Devadarvyarist.

10.Rasaaushadhi- Shilajit, Trivanga, Swarnamakshika, Vasantkusumakar, Indravati, Bhrihatbangeshwarrasa. Chandrakalarasa, Pramehagajakeshari, Pramehantak.

\section{Pathya Ahara Dravyas}

- Shooka Dhanya [Grains]: Shashtika, Shali, Yava, Godhuma, Kodrava, Shyamak, these must not be newly harvested.

- Shami Dhanya [Pulses]:_Chanaka, Adhaki, Kulattha, Mudga.

- Shaka [Vegetables]: Fresh herbs described under Tikta-varga and Kashaya-Varga ${ }^{18}$

- Mamsa [Non-Veg]: Jangala mamsa which is Laghu in nature e.g., Mriga, Dvija Mamsa which is Jangala in origin, Vishkira and Pratuda Mamsa ${ }^{19}$. These Mamsa must be Shulya i.e., roasted with the help of Shulya [Tandoor]. Mamsa of Kapota, Shash, Tittir, Lava, Bahir, Bhringraj, Vartak, Shuk etc.

- Taila [Oils]: Nikumbha, Ingudi, Sarshapa, Atasito prepare different food preparations.

- Pana [Drinks]: Sarodaka, Kushodaka, Madhudaka, Triphala Rasa, Sidhu, Sura, properly prepared Madhvika which is having premium quality and has fermented for a long time ${ }^{20}$.

Apathya Ahara Dravyas:

A diet that is responsible for the genesis of Prameha can be listed under Apathya Ahara.

- Shooka Dhanya [Grains]: Hayanaka, Chinaka, Yavaka, Naishadha, Itkata, Mukunda, Pramodaka, Sugandhaka. Freshly harvested grains.

- Shami Dhanya [Pulses]: Harenu, Masha- must not be freshly harvested and must not be taken with ghee.

- Mamsa [Non-Veg]: Gramya Mamsa, Anupa Mamsa, Audaka Mamsa.

- Milk preparations: Payasa, Ksheera, Manaka and Dadhi.
- Alcoholic preparations: Recently prepared Madya and other drinks which are sweets.

- Others: Tila, Palala, Pishtanna, Krishara, Vilepi, Kushmanda, Ikshu and Ikshuvikara, Shaka which are not mentioned in Pathya group.

3. Yogic practices: Certain yogic postures are believed to stimulate the pancreas and improve its function. Some yogic practices are effective in Diabetes mellitus; still, these yogic postures should be performed only under the guidance of a qualified yoga therapist. The duration of each yoga should be decided by the Yoga therapist.

1. Katiichakrasana, Tadasana, Pavanamuktasana, Gomukhasana, Shalabhasana, Vakrasana, Shashankasana, Dhanurasana, Mayur! sana, Pashchimottanasana, ushtrasana etc

2. Bhastrika, Bhramari, Suryabhedana pranaama.

3. Kunjala, shankhakha prakshalana, Vastra dhauti

\section{Rasayana Chikitsa:}

Acharya Sushruta and Vagbhata has described Shilajita Prayoga for Madhumeha as a Rasayana Chikitsa ${ }^{21}$. Acharya Sushruta in addition to Shilajita has also described "Swarna- makshika Prayoga' in Madhumeha ${ }^{22}$. According to Vaghbhata, it is a very potent drug and has rejuvenating power which gives better results even in those Madhumehi patients who are labelled as incurable ${ }^{23}$.

5. Counselling ${ }^{24}$ - Advice the patient to

1. Do physical activity at least $30-60$ minutes for $4-5$ days per week.

2. Increase the use of barley, wheat, Mudga and roasted chana (Bengal gram) in the diet

3. Control the use of sugar, potato, rice, milk, milk products and oily foods

4. Take care of personal hygiene especially of feet and hand

5. Avoid any kind of injury and if occur then immediately consult in case of injuries/ skin infections

6. Avoid the consumption of tobacco and liquor in any form.

7. Restrict or inhibit sweet intake.

8. Regular medical checkup and blood glucose level monitoring. 
a. Do Glycosylated haemoglobin (HbA1c) test thrice in a year

b. Eye examination annually

c. Foot examination twice in a year/ daily by the patient

d. Renal function screening yearly

e. Blood pressure quarterly

f. Lipid profile annually

g. Cardiac check-up once annually

Indications for referral:

a. Renal failure, severe infections

b. Associated with complications (diabetic foot, coronary artery disease, diabetic nephropathy, diabetic neuropathy, diabetic retinopathy etc.) and nonresponse to medication

\section{DISCUSSION}

Madhumeha is a type of Vataj Prameha which is a disease of Mutravaha Srotasa having Kapha dominancy which can be correlated with diabetes mellitus. Diabetes is not a new disease. It has gained gigantic disgrace in recent times because of increases in the prevalence of a sedentary lifestyle and obesity. Madhumeha can be prevented through lifestyle modification, diet control, and control of overweight and obesity.

The specially prepared Ayurvedic diet and lifestyle plan in the present study have all the potential to maintain the glycaemic index of Madhumeha (DM) patients. Cases of Diabetes Mellitus is increasing rapidly, because of increases in the prevalence of a sedentary lifestyle and obesity. Through appropriate use of Ayurvedic preventive measures such as Aharavidhi, Dincharya, Ritucharya and therapeutic measures Madhumeha (Diabetes Mellitus) can be prevented. The appropriate approach of diet, daily regimen, exercise, and medication can be well managed by Ayurveda.

\section{CONCLUSION}

Madhumeha (Diabetes Mellitus) can be managed conservatively with modifications in diet, exercise, medication, and lifestyle. These are all important factors in the victorious treatment of type 2 Diabetes and are assimilated into the ancient Indian medicinal practice of Ayurveda. A similar disease has been described in modern medical sciences as Diabetes Mellitus. Which has been turned out to be the considerable silent killer today within the world. In Ayurveda so many drugs have been mentioned which are found useful in the treatment of Diabetes. Recent research in Ayurveda has also proved the efficacy of various herbal and herbal drugs in Diabetes. Which are quite safe for long term use, but these drugs are effective only in mild to moderate diabetics that too become ineffective on long term use. To treat a Madhumeha Patient, a physician must have complete knowledge of different aspects of Madhumeha like Nidana, Roopa, Poorvaroopa, Samprapti, and several Chikitsa Yoga, Sadhyaasadhyta, Arishtalakshan etc. from all Samithas, Nighantu, and other literature.

\section{REFERENCES}

1. Kasper DL, Fauci A.S., Hauser S.L., Longo D.L., Jameson J.L., Loscalzo J. et.al, Harrisons Principle of Internal Medicine, Diabetes Mellitus: Diagnosis, Classification and Pathophysiology, McGraw-Hill Companies,19th Edition,2015, Vol II, 417:2399

2. Wikipedia.org/wiki/Epidemology of Diabetes Mellitus.

3. Deva Kanta R.R., editor, Shabda kalpadrum, Vol.III. First edition. Varanasi. Chaukhamba Sanskrit Se-ries ,2011, p.285.

4. Rigveda $10 / 163.15$

5. Madhava Nidana Madhavkara; Vol.-2; (English translation); Singhal G.D. at. al.; Chaukhamba Sanskrit pratisthan, Delhi; Page no.565

6. Sushruta, Pramehapidka chikitsitam. In: Dr Ambikadatta Shastri. Sushruta Samhita (Sushruta and Nagarjuna), Reprint, Varanasi, India: Chaukhambha Sanskrit Sansthan; 2006; p.63

7. Clinical Evaluation of Madhumehari Vati in the management of Madhumeha W.S.R. to Diabetes MellitusType 2 Scholar Dr Kumar Naresh, Year2014, Page-36

8. Plant Foods and Human Nutrition. March 2008; 63(1):21-5. Epub 2007 Dec 12

9. Caraka- Samhita Agnivesha; English translation; Sharma P.V. (Vol. 1); Kumar Sanju et al: An Ayurvedic Approach to Diabetes Mellitus- A Review Article "\#" www.iamj.in IAMJ: Volume 4; Issue 03; March 2016 Chaukhambha Orientalia Varanasi; Ninth edition 2005; Page.no.269.

10. Shastri A.D. Prameha chikitsa adhyaye, Ayurveda 
tatva sandeepika hindi vyakhya Chikitsa sthana, Chaukhamba Sanskrit Sansthan, 2010; 11:13 p. 3.

11. Ashtanga Hridayam, Vagbhata with Sarvangsundara and Ayurvedarasayan commentary, Chowkham-ba krishnadas Academy, Varanasi, 2006, chap. Ni.10:1, p. 502

12. Shanmugasundaram ER, Gopinath KL, Radha Shanmugasundaram K, Rajendran VM. Possible regeneration of the islets of Langerhans in streptozocindiabetic rats were given Gymnema sylvestre leaf extracts. J Ethnnopharmacol 1990; 30: 265-279

13. Leach MJ. Gymnema sylvestre for diabetes mellitus: A systematic review. J Alter Complement Med 2007; 13: $977-983$

14. Carak Samhita, by Agnivesha, Revised by AyurvedaDipika commentary of Cakrapanidatta, ed. 2006, Chowkhamba krishnadas Academy, Varanasi, cha. Ch. Su.17/78. Susruta Samhita with Nibandhasangraha Commentary of Sri Dalhanacharya, Published by Chau-khambha Orientalia, Varanasi 9th ed., cha. Su. Ni.6/30.

15. AACE Diabetes Mellitus Guidelines, 2007. Endocr Pract.;13(Suppl 1), p. 5-7.

16. Shukla V, Tripathi R., editors. Charak Samhita, Vol.II, First edition. Delhi, Chaukhambha Sanskrit Pratishthan, Chikitsa Sthana,2012, 6/15. p. 171.

17. Saxena AM, Bajpai MB, Murthy PS, Mukherjee SK. Mechanism of blood sugar lowering by a swerchirincontaining hexane fraction (SWI) of Swertia chirayita. Indian J Exp Biol 1993; 31:178-181

18. Shastri A., editor. Sushruta Samhita, Vol.I, First Edition, Varanasi. Chaukhambha Sanskrit Sansthana, Sutra Sthana,2015, 43.

19. Shastri R., Upadhyaya Y., Pandeya G, Dr Gupta B. editors, Charak Samhita, Annapanavidhi adhyaye Vol. I, First Edition. Varanasi. Chaukhambha Bharati Academy, Sutra Sthana,2009,27/47-53 p.532-533.

20. Shukla V, Tripathi R., editors. Charak Samhita, Vol.II, First edition. Delhi, Chaukhambha Sanskrit Pratishthan, Chikitsa Sthana,2012, 6/46. p.175.

21. Vishwanath L, editor. Sushruta Samhita, Chaturtha Khand Vol. I, First Edition, Varanasi. Chaukhambha Sanskrit Sansthana, Chikitsa Sthana,2015, 13/10-16. p.82, 83; Gupta A. editor, Ashtang Hridya, Vidyotini tika. Varanasi. Chaukhambha Prakashan, 2009, Chikitsa Sthana, 12/34,35,43,44.

22. Vishwanath L, editor. Sushruta Samhita, Chaturtha Khand Vol. I, First Edition, Varanasi.Chaukhambha Sanskrit Sansthana, Chikitsa Sthana,2015, 13/17,18. p.81

23. Gupta A. editor, Ashtang Hridya, Vidyotini tika. Varanasi. Chaukhambha Prakashan, 2009, Chikitsa
Sthana, $12 / 43,44$

24. AYURVEDIC MANAGEMENT OF SELECT GERIATRIC DISEASE CONDITIONS, CENTRAL COUNCIL FOR RESEARCH IN AYURVEDA AND SIDDHA, Department of AYUSH, Ministry of Health \& Family Welfare, Government of India, New Delhi 110058

\section{Source of Support: Nil \\ Conflict of Interest: None Declared}

How to cite this URL: Alisha Dhaaniya et al: A Critical Review Study On Madhumeha (Diabetes Mellitus) And Its Preventive Approach. International Ayurvedic Medical Journal \{online\} 2021 \{cited October 2021\} Available from: http://www.iamj.in/posts/images/upload/2542_2549.pdf 